\title{
Fear of Being Black in America
}

\section{Ward, Jesmyn. The Fire This Time: A New Generation Speaks about Race. Scribner, 2016. pp. 288.}

The Fire This Time, written and edited by Jesmyn Ward, is a collection of various essays, poems, and stories. It is written by different authors who describe their experiences of being black in America. The title of the book is a reference to James Baldwin's work The Fire Next Time, published about fifty years prior to this book, since it discusses the same themes of race and identity but in a more contemporary context and through voices of various authors.

The authors wrote the book in relation to all the historical events that led to the current position of black people in America while also describing their own experiences and reactions to the more contemporary events of police brutality and the Black Lives Matter movement. As Jasmyn Ward states in her introduction: "... the past is in the present, how heavily the past bears on the future; we cannot talk about black lives mattering without reckoning with the very foundation of this country," (9) so have these essayists and poets reflected upon past, from speaking of the American Civil War, The Reconstruction Era to Great Migration and The Civil Rights Movement of the 1960s; all the while describing their memories of the first time they had realized they were black, in a social and cultural sense, as well as the first time they had seen how cruel the world could be towards those who are "different." Some of them, such as Wendy S. Walters, went deeper into research rather than reaching for their own experiences; thus exploring the evidence of inhumane treatment of dead black slaves while looking into the specifically assigned graveyards in New Hampshire.

In order to give you a better understanding of all nineteen stories, we can place them into four different categories according to the stories' most prominent themes. 
The first category is one of the life and death of a black person. It is most prominent in the following stories: "The Tradition" by Jericho Brown, "Homecoming, AD" by Kima Jones, "The Weigh" by Rachel Kaadzi Ghansah, "Lonely in America" by Wendy S. Walters, "Queries of Unrest" by Clint Smith, "Composite Pops" by Mitchell S. Jackson, a poem "Theories of Time and Space" by Natasha Trethewey, and "Message to My Daughters" by Edwidge Danticat.

The second category involves stories that introduce us to the world of whiteness (privilege) while discussing limitations the black body encounters. These include: "Where Do We Go from Here?" by Isabel Wilkerson, "The Dear Pledges of Our Love: A Defense of Phillis Wheatley's Husband" by Honorèe Fanonne Jeffers, "White Rage" by Carol Anderson, "Black and Blue" by Garnette Cadogan, and "Know Your Rights!" by Emily Raboteau.

Furthermore, the following stories describe the black culture and sentiment of a community: "Introduction" and "Cracking the Code" by Jesmyn Ward, "Blacker than Thou" by Kevin Young, and "Da Art of Storytellin (a Prequel)" by Kiese Laymon.

The final category addresses the importance of revolution and change. It consists of only two stories: "The Condition of Black Life Is One of Mourning" by Claudia Rankine and "This Far: Notes on Love and Revolution" by Daniel José Older.

Throughout the book, the events most often talked about are those of police brutality. Whether it be a past event, as is the case of Abner Louima, who survived a vicious attack on his sexuality, or the more current cases of Trayvon Martin and Michael Brown, black boys killed solely for being alive. Mentions of survival techniques followed so as not to attract any attention, history always repeating and events replaying, and the ways to deal with assigned stereotypes are all themes seen, read, and talked about, now more than ever, which were a big taboo in the past; topics so painful to talk about yet so necessary in order to show how black people are treated. Books such as this one are crucial if we want to see the world advancing towards a better society; a society in which those punished would be punished for a reason, those killed, killed because there was no other way, a society in which a black person can walk through their own city or town without the fear of being arrested or shot. 
The book starts with a poem and continues into an introduction by Jesmyn Ward, the editor of the book, in which she gives the basic view into the lives of black people in America. She gives this idea of a community of black people sharing similar experiences and who now, with the popularity of online sites, can reach a much wider audience. Jesmyn Ward writes: "I believe there is power in words, power in asserting our existence, our experience, our lives, through words. That sharing our stories confirms our humanity. That it creates community ..." (10). By sharing their stories online, they have a bigger platform and a greater strength to create a community, and it also furthers them away from being merely a concept of a black person towards being a human - capable of hurting the same way as anyone else. Once you see a 17-year-old boy lying dead on the ground and realize he did nothing to have such a terrible end, the importance of understanding stereotypes aimed at the black community comes to light.

Since the text is written in such a manner that there are many different authors, the style of telling the story differs. In most cases, it is a simple storytelling technique, while some of the authors wrote in the form of a letter used to talk to their children, as was the case with Baldwin's aforementioned work or Ta-Nehisi Coates's book Between the World and Me.

One might find it to be a very interesting way of seeing all terrifying situations black people have to deal with, from police brutality, stereotypes, to having "the talk" with their children. It has a very strong emotional impact on many people. When Garnette Cadogan states the rules he put on himself: "No running, especially at night, no sudden movements, no hoodies; no objects ... ; no waiting for friends on street corners ..." (139), and Emily Raboteau shows all the pictures of murals asserting the rights one should know, the reality hits the reader in the face. It is not that people are not aware of the events, but since they are not the ones experiencing it, they seem to forget to think about it. When they do not have to walk around memorizing everything they have to do in order not to get shot by the police, they forget some people do not have this privilege. People forget it is a privilege at all, and the feeling of half anger half sadness comes upon them.

Many of the authors have mentioned having "the talk" with their children someday; the talk about why they should behave in a certain way and about the fear of that conversation because they do not know how to explain something so serious to someone so young and innocent. Today, with so much police brutality going on - children being shot for buying candy and listening to music - the 
talk seems to have to come sooner. With the era of Twitter and Instagram, children find out about everything before their parents and can see the videos and pictures of crimes. The unease of having to talk about it to a 4-year-old is something that is thematized in this book, particularly in the story "Know Your Rights!" by Emily Raboteau. Many might find this conversation in the book about "the talk" a tremendous strength of the text - revealing how parents of black children have to think about the ways to tell them, at an early age, that they might be killed for raising their hand the wrong way. Although it might be a subjective text, showing how the most innocent ones are affected by this effectively demonstrates the society that has failed an entire race of people brought there by force.

Also, one of the texts in the book having a great impact on the reader is "Blacker Than Thou" by Kevin Young. In the text, he vigorously criticizes Rachel Dolezal and the concept of blackface. What he explained so well is what blackness means to black people. He moved it away from having everything to do with the color of one's skin by saying it is "... a way of being" (109). Some people have an issue with seeing why some things are racially and culturally unacceptable, why wearing dreadlocks and braiding your hair in cornrows is insulting, and as he simply puts it, for anyone who wants to ignore the offensiveness of their actions, it is something they share as a community, something that connects them. It is not just the hair, it is the type of music they listen to, music helping them share their anger toward the world and treatment they experience, it is a way they talk. It is something specific to them that is so meaningful yet used by others as a way of looking "cool" on their Instagram accounts. It is a part of their community, something similar to what Jesmyn Ward talks about, except she mentions it in the context of loss. Probably the most popular American family today, the Kardashian-Jenners, do not seem to see anything wrong in wearing cornrows on the red carpet or posting pictures of wearing them, and no matter how many times they are told it is offensive, they turn the other cheek and often repeat the action all over again as if nothing had happened. They pretend as if an entire culture has not just been told it is inappropriate to wear a certain hairstyle, but when a rich, white person does it, it is considered a modern or urban look. Everything is judged according to one's whiteness - a scale permitting some people to do certain things, and restricting others in doing the same. This is mostly a critique of the society which had created such a vast difference between these groups of people. The society 
constantly creates these differences, passing them on to new generations, passing the hatred towards the "Other." So, the next time we ask ourselves why hair or anything people might find trivial makes another community angry, we should recall the words from the foreword of Frantz Fanon's book Black Skin - White Masks: "This anger is not a spontaneous phenomenon. It is no gut reaction or some recently discovered passion for justice and equity. Rather, it is anger borne out of the grinding experience, painfully long self-analysis, and even longer thought and reflection" (8).

Another concept noted in this book is Du Bois's "double consciousness," the division of one's identity created by the society's treatment, as in the Garnette Cadogan's story "Black and Blue." He talks about the person he thinks he truly is and the one the society had created for him. These aspects of cultural internalization are evident in "Black and Blue" when Garnette Cadogan accepts he is going to have to go by certain rules in order to survive - the rules society has obliged him to make.

To conclude, The Fire This Time is a book that discusses everything from police brutality, stereotypes, to limits a black body has in its movement. It explains the sense of community present amongst black people, offering a deeper insight aimed at a better understanding of black life from a young age, when they have to listen about all the horrific things happening, to adulthood when they are the ones having to retell them to their children. It is an important collection of experiences enabling us to hear the stories of different people who have one thing in common - the black body. Its relevance lies in its relation to the present day and recent events. It is relevant in understanding why usurping someone's culture by taking pieces of it to make it "cool," is something that can be seen as problematic since it is necessary for the world to see how deeply rooted racism is.

\section{Works Cited}

Fanon, Frantz. Black Skin, White Masks. Translated by Charles Lam Markmann, Pluto Press, 2008. 